\title{
Production of Tannase using Aspergillus niger by Submerged Fermentation
}

\author{
Mohan Kuppusamy \\ Department of Chemical \\ Engineering \\ Annamalai University \\ Annamalainagar, \\ Tamilnadu, India
}

\author{
Viruthagiri Thangavelu \\ Department of Chemical \\ Engineering \\ Annamalai University \\ Annamalainagar, \\ Tamilnadu, India
}

\author{
Suresh Baladhandayutham \\ Department of Chemical \\ Engineering \\ DDE, Engineering Wing \\ Annamalai University \\ Annamalainagar, \\ Tamilnadu, India
}

\begin{abstract}
A study on optimization of submerged fermentative production of tannase by Aspergillus niger was carried out. Aspergillus niger (MTCC 3557) was used for maximum production of Tannase enzyme and the factors affecting the production were optimized. The optimum conditions for maximum tannase enzyme production in the Submerged Fermentation (SmF) using Aspergillus niger was obtained with an initial tannic acid concentration of $3 \%(\mathrm{w} / \mathrm{v})$ at $35^{\circ} \mathrm{C}$, Initial $\mathrm{pH}$ of 5.5 and a fermentation period of $96 \mathrm{~h}$.The substrates Betalnut husk and Plantain flower gave a maximum tannase production of $19.3 \mathrm{U} / \mathrm{ml}$ and $17.89 \mathrm{U} / \mathrm{ml}$ respectively.
\end{abstract}

Keywords: Submerged fermentation, Tannase, Agro residue, Aspergillus niger. optimization

\section{INTRODUCTION}

Tannin acyl hydrolase commonly known as tannase, catalyses the hydrolysis of ester and depside bonds in hydrolysable tannins such as tannic acid, resulting glucose and gallic acid [1]. It is extensively used in food, beverages like tea and coffee, pharmaceutical and chemical industries The major commercial application of this enzyme is in the hydrolysis of gallotannin to Gallic acid, is an intermediate required for the synthesis of an antifolic, antibacterial drug trimethoprim[2]. Tannase is also used in the preparation of instant tea, wine, beer and coffee-flavored soft drinks and also as additive for detannification of food. Many fungi, such as Aspergillii, Penicillii, Fusaria, and Trichoderma [36] as well as yeast like Candida sp., and Saccharomyces cerevisiae [7] have been reported to be tannase producers. On the other hand, few bacteria are known to produce tannase and include certain species of Bacilli, Corynebacterium sp., Lactobacillus sp., and Serratia sp., [8, 9]. In Industrial level tannase is mainly produced by Aspergillus species under submerged fermentation $(\mathrm{SmF})$.The $\mathrm{SmF}$ is widely used for enzyme production because it offers many advantages like uniform process conditions namely concentration, Temperature, $\mathrm{pH}$, aeration and agitation in the bioreactors [10]. Many authors reported the tannase production by Aspergillus species in the medium containing pure tannic acid as both inducer and carbon source. Agro residues and forest products are generally considered as the best sources of tannin rich substrates for $\mathrm{SmF}$ [11].

\section{MATERIALS AND METHODS}

\subsection{Substrate preparation}

Powdered Agro residues were used for the production of Tannase enzymes. The Agro residues betalnut husk and plantain flower were powdered to 100 mesh $(0.15 \mathrm{~mm})$ fine powders using laboratory grinder at $3000 \mathrm{rpm}$ and was preserved in a sealed plastic bag at $4^{\circ} \mathrm{C}$ to prevent any possible degradation or spoilage.

\subsection{Microorganism and culture maintenance}

The tannase producing fungal culture Aspergillus niger (MTCC 3557) was obtained from IMTECH, Chandigarh and was used for tannase production. The fungal culture was maintained on Czapek Dox media agar slants supplemented with $1 \%(\mathrm{w} / \mathrm{v})$ tannic acid as the sole carbon source. The fungal strain was subcultured periodically, grown at $30^{\circ} \mathrm{C}$ for 7 days. The well grown culture was stored at $4^{\circ} \mathrm{C}$ in a refrigerator and used for further subculturing.

\subsection{Production of Tannase in submerged fermentation $(\mathrm{SmF})$}

$100 \mathrm{ml}$ of Czapek Dox medium in $250 \mathrm{ml}$ Erlenmeyer flask was inoculated with the Aspergillus niger spore suspension. The composition of the Czapek Dox medium used for tannase enzyme production was Tannic Acid - $10 \mathrm{~g} / \mathrm{L}$, Sodium nitrate - $6 \mathrm{~g} / \mathrm{L}$, Potassium dihydrogen orthophosphate- $1.52 \mathrm{~g} / \mathrm{L}$, Magnesium sulphate- $0.52 \mathrm{~g} / \mathrm{L}$, Potassium chloride- $0.52 \mathrm{~g} / \mathrm{L}$, Ferrous sulphate- $0.01 \mathrm{~g} / \mathrm{L}$ and Zinc sulphate- $0.01 \mathrm{~g} / \mathrm{L} .3 \mathrm{gm}$ of substrates were added separately to the Czapek Dox medium for studying their effect on the enzyme production. The cultures were grown at $30^{\circ} \mathrm{C}, 140 \mathrm{rpm}$ for six days in an incubator shaker. The samples were withdrawn at regular intervals of $24 \mathrm{~h}$. The biomass was separated by the filtration through Whatman No.1 filter paper. The cell free culture broth was assayed for the tannase activity.

\subsection{Tannase assay}

Tannase activity was estimated by the method of Mondal and Pati [12]. $0.1 \mathrm{ml}$ of enzyme solution was incubated with $0.3 \mathrm{ml}$ of $1.0 \%(\mathrm{w} / \mathrm{v})$ tannic acid and add $5 \mathrm{ml}$ of $0.2 \mathrm{M}$ acetate buffer $\left(\mathrm{pH} \mathrm{5.0)}\right.$ at $40{ }^{\circ} \mathrm{C}$ for $10 \mathrm{~min}$ and then the enzyme production was stopped by cooling to $0^{\circ} \mathrm{C}$ by the addition of $2 \mathrm{ml}$ Bovine Serum Albumin (BSA) $(1 \mathrm{mg} / \mathrm{ml}$ ), which precipitates the remaining tannic acid simultaneously A control without the enzyme was incubated and the samples were analyzed. The tubes were then centrifuged 
$(5,000 \mathrm{x} \mathrm{g}, 10 \mathrm{~min})$ and the precipitate was dissolved in $2 \mathrm{ml}$ of Sodium Dodecyl Sulphate (SDS) - triethanolamine $(1 \% \mathrm{w} / \mathrm{v}$ SDS in $5 \% \mathrm{v} / \mathrm{v}$ triethanolamine) solution and the absorbency was measured at $550 \mathrm{~nm}$ after addition of $1 \mathrm{ml}$ of $\mathrm{FeCl}_{3}\left(0.01 \mathrm{M} \mathrm{FeCl}_{3}\right.$ in $\left.0.01 \mathrm{~N} \mathrm{HCl}\right)$.

One Unit of the tannase enzyme is defined as the amount of enzyme required to hydrolyse $1 \mu$ mole of ester linkage of tannic acid in $1 \mathrm{~min}$ at specific condition.

\section{RESULTS AND DISCUSSION}

\subsection{Effect of substrate on production of Tannase}

The effect of substrate on tannase enzyme activity in submerged fermentation using Aspergillus niger was studied by conducting experiments with substrates Betalnut husk and Plantain flower. The flasks containing Czapek Dox media was incubated with $3 \%(\mathrm{w} / \mathrm{v})$ of the above mentioned substrates in an incubated rotary shaker at $35^{\circ} \mathrm{C}$, $\mathrm{pH} 5.5$ and $200 \mathrm{rpm}$. The samples were drawn at regular time intervals of $24 \mathrm{~h}$ and analyzed for tannase activity at $24 \mathrm{~h}, 48 \mathrm{~h}, 72 \mathrm{~h}, 96 \mathrm{~h}, 120 \mathrm{~h}$ and $144 \mathrm{~h}$. The results are given in Table 1 and Fig. 1 for tannase activity obtained at different timings with substrates Betalnut husk and Plantain flower. The substrates Betalnut husk and Plantain flower gave the maximum tannase activity of $19.3 \mathrm{U} / \mathrm{ml}$ and $17.89 \mathrm{U} / \mathrm{ml}$ respectively at a fermentation period of $96 \mathrm{~h}$. This higher production with Betalnut husk and Plantain flower may be due to the higher tannin content and also the substrates are easily metabolizable by A.niger. After $96 \mathrm{~h}$ of fermentation, the enzyme production was found to decrease because of the inhibition and denaturation of tannase enzyme. The maximum tannase production was obtained with substrates Betalnut husk and Plantain flower and were selected for further studies on tannase enzyme production for $96 \mathrm{~h}$. Sabu et al reported that $96 \mathrm{~h}$ of fermentation period gave the maximum tannase production with palm kernel cake as substrate [13] which is in good agreement with the current results obtained.

Table 1. Effect of Substrate on production of Tannase using Aspergillus niger

\begin{tabular}{|c|c|c|}
\hline \multirow{2}{*}{$\begin{array}{c}\text { Incubation } \\
\text { Time }(\mathrm{h})\end{array}$} & \multicolumn{2}{|c|}{ Tannase Activity (U/ml) } \\
\cline { 2 - 3 } & $\begin{array}{c}\text { BETALNUT } \\
\text { HUSK }\end{array}$ & $\begin{array}{c}\text { PLANTAIN } \\
\text { FLOWER }\end{array}$ \\
\hline 0 & 0 & 0 \\
\hline 24 & 6.85 & 5.78 \\
\hline 48 & 11.22 & 10.11 \\
\hline 72 & 14.21 & 13.64 \\
\hline 96 & 19.3 & 17.89 \\
\hline 120 & 15.32 & 13.12 \\
\hline 144 & 10.25 & 8.33 \\
\hline
\end{tabular}

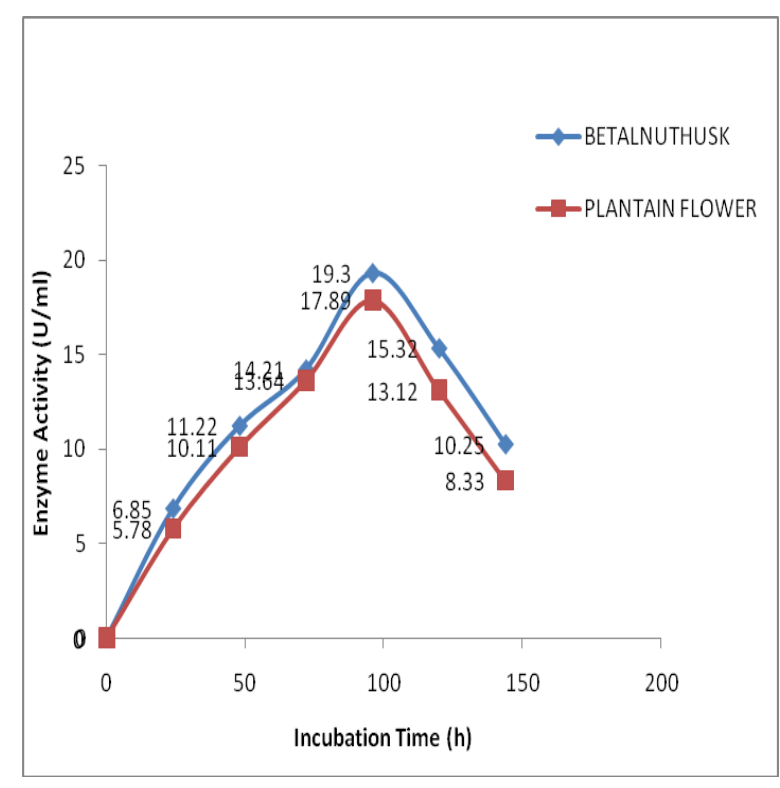

Fig 1. Effect of Substrate on production of Tannase using Aspergillus niger

\subsection{Effect of Temperature on production of Tannase}

The effect of temperature on tannase enzyme production was studied by conducting experiments at different temperatures namely $25^{\circ} \mathrm{C}, 30^{\circ} \mathrm{C}, 35^{\circ} \mathrm{C}, 40^{\circ} \mathrm{C}$ and $45^{\circ} \mathrm{C}$ keeping other parameters constant at $\mathrm{pH} 5.5,200 \mathrm{rpm}$ with the tannic acid concentration of $3 \%(\mathrm{w} / \mathrm{v})$.The results are given in Table 2 and Fig 2. As temperature was increased the maximum tannase enzyme production was found to increase rapidly. The maximum enzyme production obtained were $4.08 \mathrm{U} / \mathrm{ml}, 5.09 \mathrm{U} / \mathrm{ml}, 12.48 \mathrm{U} / \mathrm{ml}, 10.84$ $\mathrm{U} / \mathrm{ml}$ and $7.22 \mathrm{U} / \mathrm{ml}$ at $25^{\circ} \mathrm{C}, 30^{\circ} \mathrm{C}, 35^{\circ} \mathrm{C}, 40^{\circ} \mathrm{C}$ and $45^{\circ} \mathrm{C}$ respectively with Betalnut husk as a substrate. The maximum enzyme production obtained with Plantain flower as a substrate were $4.01 \mathrm{U} / \mathrm{ml}, 4.56 \mathrm{U} / \mathrm{ml}, 10.10 \mathrm{U} / \mathrm{ml}, 6.86$ $\mathrm{U} / \mathrm{ml}$ and $3.45 \mathrm{U} / \mathrm{ml}$ at $25^{\circ} \mathrm{C}, 30^{\circ} \mathrm{C}, 35^{\circ} \mathrm{C}, 40^{\circ} \mathrm{C}$ and $45^{\circ} \mathrm{C}$ respectively. At low temperatures $25^{\circ} \mathrm{C}$ and $30^{\circ} \mathrm{C}$ the rate of enzyme production was found to be less and the maximum enzyme production was found to be less. At high temperature of $40^{\circ} \mathrm{C}$ and $45^{\circ} \mathrm{C}$ the growth rate of A.niger was found to be less and this phenomena is similar to catalyst deactivation or catalyst poisoning in chemical catalysts. The enzyme probably got denatured which in turn resulted in less enzyme production. The maximum tannase enzyme production of $12.48 \mathrm{U} / \mathrm{ml}$ and $10.10 \mathrm{U} / \mathrm{ml}$ were obtained at $35^{\circ} \mathrm{C}$ and was chosen as the optimum temperature for Betalnut husk and Plantain flower as substrates respectively. The optimum temperature $35^{\circ} \mathrm{C}$ was used for further studies. The optimum temperature was $30^{\circ} \mathrm{C}$ for various fungi such as A. tamari [14], A. niger[15] and A.flavus[16] which is in good agreement with the current results obtained.

Table 2. Effect of Temperature on Production of Tannase using Aspergillus niger

\begin{tabular}{|c|c|c|}
\hline \multirow{2}{*}{$\begin{array}{c}\text { Temperature } \\
\left({ }^{\circ} \mathrm{C}\right)\end{array}$} & \multicolumn{2}{|c|}{ Tannase Activity (U/ml) } \\
\cline { 2 - 3 } & $\begin{array}{c}\text { BETALNUT } \\
\text { HUSK }\end{array}$ & $\begin{array}{c}\text { PLANTAIN } \\
\text { FLOWER }\end{array}$ \\
\hline 25 & 4.08 & 4.01 \\
\hline 30 & 5.09 & 4.56 \\
\hline 35 & 12.48 & 10.10 \\
\hline 40 & 10.84 & 6.86 \\
\hline 45 & 7.22 & 3.45 \\
\hline
\end{tabular}




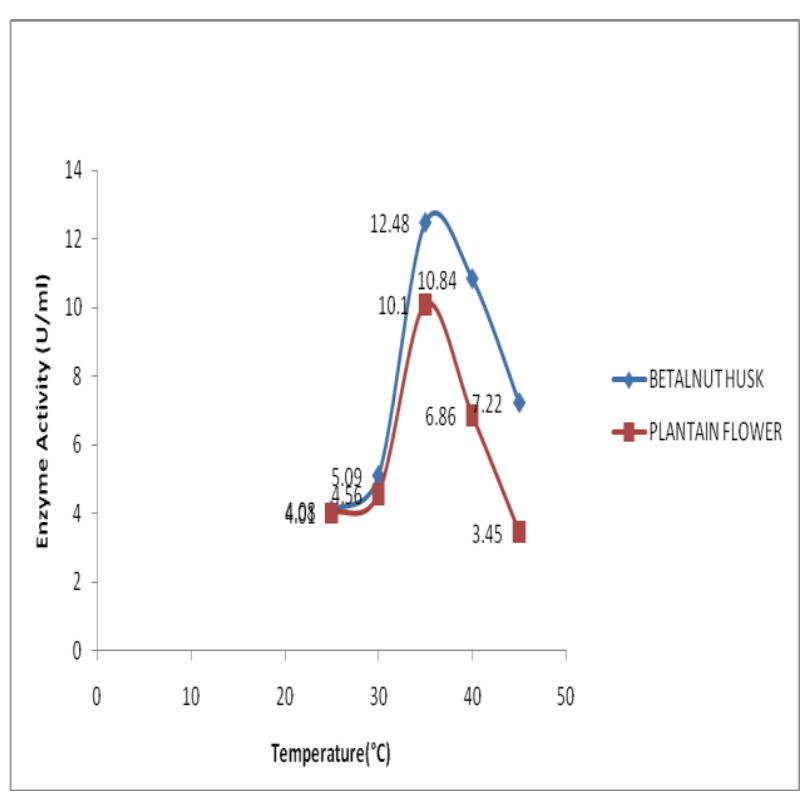

Fig 2: Effect of Temperature on the production of Tannase using Aspergillus niger

\subsection{Effect of pH on production of Tannase}

The effect of $\mathrm{pH}$ on tannase enzyme production was studied by conducting experiments at different initial $\mathrm{pH}$ namely 4.5, 5, 5.5, 6 and 6.5 keeping other parameters constant at temperature $35^{\circ} \mathrm{C}, 200 \mathrm{rpm}$ with the tannic acid concentration of $3 \%(\mathrm{w} / \mathrm{v})$. The results are given in Table 3 and Fig 3.As $\mathrm{pH}$ was increased the tannase enzyme production was found to increase. The growth rate was less at low $\mathrm{pH}$ and was maximum at $\mathrm{pH} 5.5$ and thereafter the growth rate was decreasing, resulting in the lesser yield of biomass. Since the enzyme is a growth associated product, the enzyme was found to be maximum at $\mathrm{pH}$ 5.5.The maximum tannase enzyme production obtained were 7.2 $\mathrm{U} / \mathrm{ml}, 10.43 \mathrm{U} / \mathrm{ml}, 18.4 \mathrm{U} / \mathrm{ml}, 12.3 \mathrm{U} / \mathrm{ml}$ and $6.2 \mathrm{U} / \mathrm{ml}$ at $\mathrm{pH}$ 4.5, 5, 5.5, 6 and 6.5 respectively with Betalnut husk as a substrate. The maximum enzyme production obtained with Plantain flower as a substrate were $6.6 \mathrm{U} / \mathrm{ml}, 8.74 \mathrm{U} / \mathrm{ml}$, $14.7 \mathrm{U} / \mathrm{ml}, 11.2 \mathrm{U} / \mathrm{ml}$ and $3.2 \mathrm{U} / \mathrm{ml}$ at $\mathrm{pH} \mathrm{4.5,} \mathrm{5,} \mathrm{5.5,} 6$ and 6.5 respectively. The maximum tannase enzyme production of $18.4 \mathrm{U} / \mathrm{ml}$ and $14.7 \mathrm{U} / \mathrm{ml}$ were obtained for $\mathrm{pH} 5.5$ for Betalnut husk and Plantain flower as substrates respectively and was chosen as the optimum $\mathrm{pH}$. Lekha and Lonsane [10] also reported that tannases are acidic proteins with an optimum pH 5.5. Rakeshkumar et al. [17] reported an optimum $\mathrm{pH}$ of 5.5 for tannase production by Aspergillus ruber, Aspergillus awamori [18] which is in good agreement with the current results Obtained

Table 3. Effect of pH on Production of Tannase using Aspergillus niger

\begin{tabular}{|c|c|c|}
\hline \multirow{2}{*}{$\mathrm{pH}$} & \multicolumn{2}{|c|}{ Tannase Activity (U/ml) } \\
\cline { 2 - 3 } & $\begin{array}{c}\text { BETALNUT } \\
\text { HUSK }\end{array}$ & $\begin{array}{c}\text { PLANTAIN } \\
\text { FLOWER }\end{array}$ \\
\hline 4.5 & 7.2 & 6.6 \\
\hline 5.0 & 10.43 & 8.74 \\
\hline 5.5 & 18.4 & 14.7 \\
\hline 6.0 & 12.3 & 11.2 \\
\hline 6.5 & 6.2 & 3.2 \\
\hline
\end{tabular}

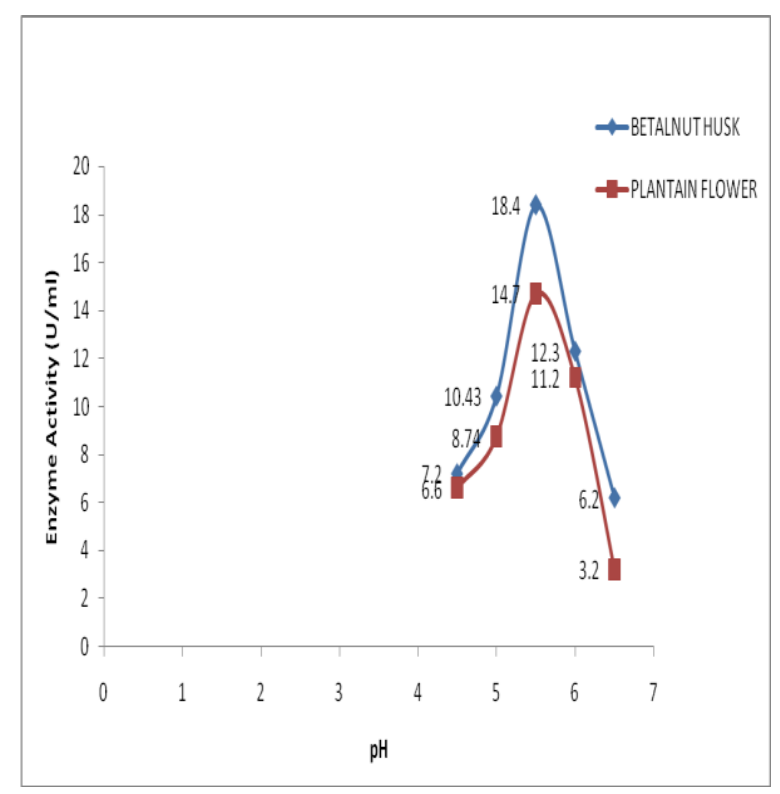

Fig 3. Effect of $\mathrm{pH}$ on the production of Tannase using Aspergillus niger

\subsection{Effect of concentration of Tannic acid (Inducer) on production of Tannase}

The effect of concentration of tannic acid on tannase enzyme production as inducer was studied by conducting experiments at different concentrations namely $1 \%, 2 \%$, $3 \%, 4 \%$ and $5 \%$ keeping other parameters constant at temperature $35^{\circ} \mathrm{C}, \mathrm{pH} 5.5$ and $200 \mathrm{rpm}$. The results are given in Table 4 and Fig 4 . As the tannic acid concentration was increased the tannase enzyme production was found to increase. The maximum enzyme production obtained were $7.44 \mathrm{U} / \mathrm{ml}, 12.6 \mathrm{U} / \mathrm{ml}, 19.1 \mathrm{U} / \mathrm{ml}, 17.43 \mathrm{U} / \mathrm{ml}$ and $8.32 \mathrm{U} / \mathrm{ml}$ at tannic acid concentration of $1 \%, 2 \%, 3 \%, 4 \%$ and $5 \%$ respectively with Betalnut husk as a substrate. The maximum enzyme production obtained were $2.86 \mathrm{U} / \mathrm{ml}, 7.9$ $\mathrm{U} / \mathrm{ml}, 16.1 \mathrm{U} / \mathrm{ml}, 14.8 \mathrm{U} / \mathrm{ml}$ and $6.45 \mathrm{U} / \mathrm{ml}$, at tannic acid concentration of $1 \%, 2 \%, 3 \%, 4 \%$ and $5 \%$ respectively with Plantain flower as a substrate. The maximum tannase enzyme production of $19.1 \mathrm{U} / \mathrm{ml}$ and $16.1 \mathrm{U} / \mathrm{ml}$ were obtained with Betalnut husk and Plantain flower as substrates respectively at tannic acid concentration of 3\% $(\mathrm{w} / \mathrm{v})$ and was chosen as the optimum tannic acid concentration. The optimum tannic acid concentration 3\% $(w / v)$ was used for further studies. The enzyme production was found to decrease at higher inducer concentration of $4 \%$ and $5 \%$ and may be due to the substrate inhibition of inducer. At higher tannic acid concentration tannase activity was higher in SSF whereas it was repressed in submerged fermentation [19]. Actually, tannic acid at higher concentration produces complexes with protein of the organism thereby inhibits the growth and reduces the enzyme production [20]. 
Table 4. Effect of Tannic Acid concentration on Production of Tannase using A.niger

\begin{tabular}{|c|c|c|}
\hline \multirow{2}{*}{$\begin{array}{c}\text { Tannic acid } \\
\text { Concentration } \\
(\%)\end{array}$} & \multicolumn{2}{|c|}{ Tannase Activity (U/ml) } \\
\cline { 2 - 3 } & $\begin{array}{c}\text { BETALNUT } \\
\text { HUSK }\end{array}$ & $\begin{array}{c}\text { PLANTAIN } \\
\text { FLOWER }\end{array}$ \\
\hline 1 & 7.44 & 2.86 \\
\hline 2 & 12.6 & 7.9 \\
\hline 3 & 19.1 & 16.1 \\
\hline 4 & 17.43 & 14.8 \\
\hline 5 & 8.32 & 6.45 \\
\hline
\end{tabular}

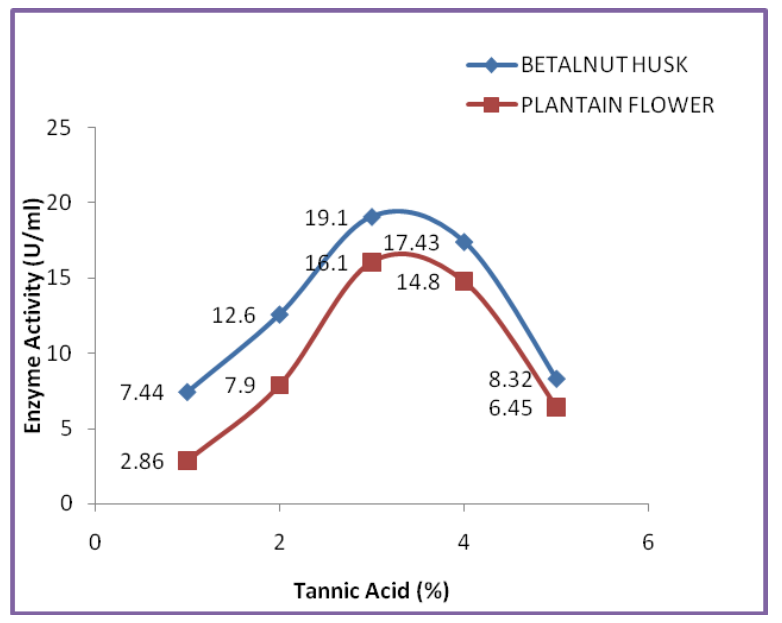

Fig 4: Effect of Tannic Acid on the production of Tannase using Aspergillus niger

\section{CONCLUSION}

The present investigation shows that agro residues such as Betalnut husk and Plantain flower were found to be the best and most cost effective substrates for the industrial production of microbial tannase. The tannase produced by Aspergillus niger was significant and this fact encourages further exploitation of tannase production at industrial scale. The optimum substrate concentration found to be $3 \%(\mathrm{w} / \mathrm{v})$ of Betalnut husk and Plantain flower and optimum inducer concentration of $3 \%(\mathrm{w} / \mathrm{v})$ tannic acid. The optimum temperature, $\mathrm{pH}$, agitation speed and fermentation period were found to be $35^{\circ} \mathrm{C}, 5.5,200 \mathrm{rpm}$ and $96 \mathrm{~h}$ respectively.

\section{ACKNOWLEDGMENTS}

The authors express their sincere thanks to the Bioprocess research Laboratory, Department of Chemical Engineering, Annamalai University for providing the necessary facilities for the successful completion of this research work.

\section{REFERENCES}

[1] Banerjee Rintu, Mukherjee Gargi and Patra, Krushna Chandra. May 2005, Microbial transformation of tanninrich substrate to gallic acid through co-culture method.Bioresource Technology, vol. 96, no. 8, p. 949-953.

[2] Hadi, T.A., Banerjee, R., Bhatacharya, B.C., 1994.Optimization of tannase biosynthesis by a newly isolated Rhizopus oryzae. Bioprocess Eng. 11, 239-243.

[3] Bradoo, S., Gupta, R., and Saxena, R. K. ., 1996 Screening of extracellular tannase producing fungi.
Development of a rapid and simple plate assay, J. Gen. Appl. Microbiol., 42, 325-329.

[4] Batra, A. and Saxena, R. K., 2005, Potential tannase producers from the genera Aspergillus and Penicillium, Process Biochem., 40, 1553-1557.

[5] Murugan, K., Saravanababu, S., and Arunachalam, M., 2007, Screening of tannin acyl hydrolase (E.C.3.1.1.20) producing tannery effluent fungal isolates using simple agar plate and SmF process, Bioresour. Technol., 98, 946-949.

[6] Paranthaman, R., Vidyalakshmi, R., Murugesh, S., and Singaravadivel, K, 2009, Optimization of various culture media for tannase production in submerged fermentation by Aspergillus flavus, Adv. Biol. Res., 3, 34-39.

[7] Mondal, K. C., Banerjee, D., Banerjee, R., and Pati, B, 2001, Production and characterization of tannase from Bacillus cereus KBR9, J. Gen. Appl. Microbiol., 47,263267.

[8] Rodríguez, H., De las Rivas, B., Gómez-Cordovés, C., and Munoz, R., 2008, Degradation of tannic acid by cellfree extracts of Lactobacillus plantarum, Food Chem., 107, 664-670.

[9] Milva, P., Lucia, R. L., Roberto, A., Alessandro, E., Guido, P., Monia, R., Arianna, L., Antonio, F., Simone, G., and Silvano, E. F., 2010, Tannic acid degradation by bacterial strains Serratia spp. and Pantoea sp. isolated from olive mill waste mixtures, Int.Biodeter. Biodegr., 64, 73-80.

[10] Lekha P.K. and Lonsane B.K., 1997, Production and application of tannin acyl hydrolase. State of the art, Advances in Applied Microbiology., 44, 215-260.

[11] Lokeswari.N., 2010, Microbial production of Gallicacid by a mutant strain of Aspergillus oryzae using Cashew husk, Pharmacopore., 1, 112-122.

[12] K.C.Mondal, D. Banerjee, M.Jana and B.R. Pati , 2001, Colorimetric assay method for determination of tannin Acyl hydrolase (EC. 3.1.1.20) activity, Analytical Biochemistry, 295, 168-171.

[13] Sabu A, Pandey A, Jaafar Daud M. and Szakacs G., 2005, Tamarind seed powder and palm kernel cake: two novel agro residues for the production of tannase under solid state fermentation by Aspergillus niger ATCC 16620. Biores. Technol., 96, 1223-1228.

[14] Simeon Chukwuemeka Enemuor and Fredrick John Chidi Odibo, 2010, Partial purification and characterization of Aspergillus tamari IMI388810 (B) tannin acyl hydrolase, Archives of Applied Science Research, 2 (6): 290-299

[15] Deepanjali Lal and Joy Joseph Gardner, 2012, Production, characterization and purification of tannase from Aspergillus niger,European Journal of Experimental Biology, 2 (5):1430-1438

[16] Mohan Kuppusamy, Viruthagiri Thangavelu and Arunkumar Chockalingam., 2012, optimization of submerged fermentative production of Tannase by Aspergillus flavus International Journal of ChemTech Research, 4 (4), 1461-1467 
[17] Rakesh Kumar, Jitender Sharma and Randhir Singh, 2007, Production of tannase from Aspergillus ruber under solid-state fermentation using jamun (Syzygium cumini) leaves,Microbiol research ,162, 384-390

[18] Suresh Baladhandayutham and Viruthagiri Thangavelu, 2011, Optimization and Kinetics of Solid-State Fermentative Production of Pectinase by Aspergillus awamori, International Journal of ChemTech Research, 3 (4), $1758-1764$.

[19] P.K.Lekha and B.K.Lonsane, 1994, Comparative Titres, Location and Properties of Tannin Acyl Hydrolase produced by Aspergillus niger PKL104 in Solid-state, Liquid surface and Submerged fermentations, Process Biochemistry, 29, 497-503.

[20] D.Banerjee, K.C.Mondal and B.R.Pati, 2007, Tannase production by Aspergillus aculeatus DBF9 through Solid state fermentation, Acta Microbiologica et Immunologica Hungarica, 54 (2):159-166. 